\title{
PROFESSIONAL CORPORATIONS
}

\author{
JOHN A. DUNKEL*
}

For years self-employed professional men and women have been acutely aware of their lack of equal treatment under the Federal income tax laws. Unable to incorporate, and thus employ themselves, they have been denied the "fringe benefits" which the Internal Revenue Code makes available only to employees. Various attempts have been made to equalize the status of the self-employed, the best known of which is the Jenkins-Keogh Bill (H.R. 10). This bill, which failed to pass in the last ten sessions of Congress, ${ }^{1}$ would provide for the tax free deferment of a certain amount of income for retirement purposes. In the past there has apparently been insufficient political weight to force the equalization of tax benefits. Now, however, state legislation during the 1960-61 session permitting incorporation of self-employed professionals will undoubtedly require Congress to give the matter more serious consideration. ${ }^{2}$

The Ohio act cannot be approached without some knowledge of the circumstances which led to its enactment. The incorporated practice of law or medicine is a sharp departure from long standing policy. There is but a single reason for changing this policy-to create an entity capable of employing the professional so as to allow him the same opportunity to reduce his Federal income tax presently open to the non-professional. The stakes are large, particularly for those professionals in high income tax brackets. The major tax incentives are:

(A) An employer's contributions to either a pension or profit sharing trust for the benefit of his employees are deductible by the employer when made $e^{3}$ but not includible in the income of the employee until received from the trust during low income retirement years. ${ }^{4}$ In addition, the trust's income is exempt thus it may be reinvested tax free. ${ }^{5}$ In the case of profit sharing plans these contributions can be as much as $15 \%$ of the participating employees'

* Of the firm of Porter, Stanley, Treffinger \& Platt, Columbus, Ohio; former Special Attorney, Office of the Chief Counsel, Internal Revenue Service.

1 For a detailed discussion of the history and provisions of the bill see, Rapp, "Pensions for the Self-Employed: The Treasury Department-Finance Committee Plan," 16 Tax L. Rev. 227 (1961).

2 The situation is reminiscent of the rash of state community property laws enacted in the late 1940's to permit a husband and wife to split income. Congress provided for the same result in the Revenue Act of 1948 by creating the joint income tax return.

3 Int. Rev. Code of 1954, § 404(a).

4 Int. Rev. Code of 1954, \& 402(a)(1).

5 Int. Rev. Code of 1954, $\$ 501(\mathrm{a})$. 
annual compensation. ${ }^{6}$ Contributions to a pension plan are limited to $5 \%$ of the employees' compensation, or the actual cost of the plan plus $10 \%$ of the cost of funding past service. ${ }^{7}$ If both plans are adopted, the overall limitation on the amount of income which may be deducted (and thus deferred) is $25 \%$ of the beneficiaries' annual compensation. $^{8}$ If the employee takes his share of the trust in a lump sum at separation he may treat the entire amount received as long term capital gain. ${ }^{\circ}$ The maximum tax is thus $25 \%$ upon complete withdrawal of the fund.

(B) Premiums on group term life insurance policies and group health and accident policies paid by the employer are deductible by him $^{10}$ and not taxable to his employees. ${ }^{11}$

(C) Employees can receive up to $\$ 100$ per week tax-free during a period of injury or illness under an employer financed plan. ${ }^{12}$

(D) Amounts up to $\$ 5,000$ paid by an employer to the beneficiaries or the estate of a deceased employee may be received tax free. ${ }^{13}$

As mentioned above, Congress has evidenced no particular interest in equalizing the income tax status of the self-employed. Dispairing of the unsympathetic attitude of Congress, some professional groups, although prohibited from practicing their professions through the medium of a corporation, attempted another avenue of attaining entity status within the framework of the Internal Revenue Code itself. Under Section 7701 of the Internal Revenue Code, the definition of a "corporation" for Federal income tax purposes is not limited to the artificial entity commonly known as a corporation, but includes associations, joint stock companies, and insurance companies. The purpose of this provision, which has been in the law for many years, ${ }^{14}$ is to tax the income of business trusts and similar types of hybrid organizations which have most of the characteristics of corporations except a charter. The leading case on the subject, Morrissey v. Commissioner, ${ }^{15}$ set forth the principal characteristics which, if possessed by an organization, would tend to cause it to be treated as a corporation under the Internal Revenue Code. These characteristics are: (1) associates, (2) an objective to carry on business and divide the

6 Int. Rev. Code of 1954,404 (a) (3).

7 Int. Rev. Code of 1954, \& 404(a)(1).

8 Int. Rev. Code of 1954, \& 404(a) (7).

9 Int. Rev. Code of 1954, § 402 (a) (2).

10 Int. Rev. Code of 1954, $\$ 162$; L.O. 1014, 2 Cum. Bull. 88 (1920); Treas. Reg. 162-10(a) (1958).

11 G.C.M. 16069, XV-1 Cum. Bull. 84 (1936); Int. Rev. Code of 1954, § 106.

12 Int. Rev. Code of 1954, § 105 (d).

13 Int. Rev. Code of 1954, \& 101 (b).

14 Originally enacted as Section 1 of the Revenue Act of 1918.

15296 U.S. 344 (1935). 
gains therefrom, (3) continuity of life, (4) centralization of management, (5) liability for corporate debts limited to corporate property, and (6) free transferability of interests.

Using section 7701, groups of physicians began organizing clinics under articles of association containing as many corporate characteristics as possible. Although technically partnerships under local law, the associations sought corporate status under the Internal Revenue Code. These associations experienced some success in the courts $^{16}$ but on November 15, 1960 the Commissioner of Internal Revenue adopted final regulations under Section 7701 of the 1954 Code. These regulations require that a general partnership, in order to be classified as an association taxable as a corporation for Federal income tax purposes, must have, in addition to associates and business purpose, at least three of the remaining four corporate characteristics. ${ }^{17}$ Further, the regulations in effect provide that a general partnership subject to a statute corresponding to the Uniform Partnership Act lacks a sufficient number of these elements. ${ }^{18}$ Thus in 38 states which have the Uniform Partnership Act, ${ }^{19}$ there was a serious setback to the association approach to equal status for the professional self-employed.

Suffering defeat from both Congress and the Commissioner, professional groups turned to their state legislatures for some type of entity which would be recognized as a corporation for Federal income tax purposes. At the date of this writing some thirteen states have passed acts to allow either the incorporation of professional practice or the formation of special types of associations intended to have a sufficient number of corporate characteristics to meet the requirement of the regulations. ${ }^{20}$ The Ohio version follows the corporate approach and provides for the incorporation of professional practice under the General Corporation Law subject to the limitations found in the new act. Although the title of the act states that it is ". . . to permit the

16 Pelton v. Commissioner, 82 F.2d 473 (7th Cir. 1936); United States v. Kintner, 216 F.2d 418 (9th Cir. 1954); Galt v. United States, 175 F. Supp. 360 (N.D. Tex. 1959). For further discussion see, Ray, "Corporate Tax Treatment of Medical Clinics Organized as Associations," 39 Taxes 73 (1961).

17 Treas. Reg. \& 7701-2(a) (3) (1960).

18 Treas. Reg. $\$ 7701-2$ (b) (3), (c) (4), (d) (1960).

19 Ohio Rev. Code, Ch. 1775.

20 The states that have enacted professional corporation acts are: Arkansas (physicians and dentists only), Florida, Minnesota (physicians only), Ohio, Oklahoma, South Dakota (physicians only) and Wisconsin. Professional association acts were passed in: Alabama, Connecticut, Georgia (physicians only), Illinois, Pennsylvania, and Tennessee. Nebraska permits physicians to incorporate under a decision of its supreme court. 
establishment of professional associations," a corporation under Ohio law. The major features of the act, now Sections 1785.01 to 1785.08 of the Revised Code, are summarized as follows:

Section 1785.01(A) lists the professions which may incorporate under the act by defining "professional service" as that performed by certified public accountants, licensed public accountants, architects, attorneys, dentists, pharmacists, optometrists, physicians and surgeons, practitioners of limited branches of medicine or surgery as defined in Section 4731.15 of the Revised Code (chiropractic, naprapathy, spondylotherapy, mechanotherapy, etc.), professional engineers and veterinarians.

Section 1785.01(B) defines a "professional association" as one organized under the act for the sole purpose of rendering a professional service.

Section 1785.02 limits the organization and shareholding of a professional association to an individual or a group of individuals rendering the same kind of professional service within Ohio.

Section 1785.03 provides that a professional association may render services only through officers, employees and agents licensed to render the professional service in Ohio. Clerks, bookkeepers, technicians and others incident to the practice of the profession but not by custom considered to be rendering professional services, are not "employees" for this purpose. The same is true of other persons who perform all their employment under the supervision and control of a duly licensed professional.

Section 1785.04 states that the act does not modify any law applicable to the personal relationship between the professional and the person for whom he performs services, including liability arising out of the professional service.

Sections 1785.05 and 1785.07 prevent the issuance, sale or transfer of the stock of a professional association to any person who is not licensed or otherwise legally authorized to render the same professional service as that for which the corporation was organized.

Section 1785.06 requires an annual report to the secretary of state certifying the qualifications of the shareholders of the corporation.

Section 1785.08 makes Chapter 1701 of the Revised Code, the General Corporation Law, applicable to professional associations, including their organization and their manner of filing articles of

21 The full title is: Amended Senate Bill No. 550. "To enact sections 1785.01 to 1785.08, inclusive, and to amend section 4715.18 of the Revised Code to permit the establishment of professional associations." 
incorporation, except that in case of a conflict, the provisions of the new act take precedence. Section 1701.06(A) of the Revised Code, relating to the express terms of shares, is specifically excepted from application.

In substance, the act intends that individuals engaged in the practice of a profession may incorporate just as non-professionals. Although there are differences due to ethical considerations, the factors involved in the decision of whether or not to incorporate should remain much the same as those in any personal service organization. Ethical considerations, although of considerable importance, must be left to others more qualified to discuss them. ${ }^{22}$

From an income tax standpoint, incorporation. offers the advantages outlined above. However, the organization of a professional corporation creates a taxable entity and the possibility of a double tax on professional income. In professional corporations with not more than ten shareholders this should present no problem. Subchapter $S$ of the Internal Revenue Code provides that if all shareholders consent, the income of the corporation will be taxed directly to them in much the same manner as a partnership. ${ }^{23}$ The election does not disturb the beneficial incidents of corporate status, but simply removes the aspect of double taxation on corporate earnings when received and as dividends when distributed to shareholders.

Where there are more than ten shareholders the election is not available and the avoidance of corporate tax becomes a problem. In what will probably be the normal case, the entire net income of the corporation, after other expenses, will be paid out to shareholders in the form of compensation. Compensation paid to employees is deductible by a corporation in arriving at taxable income, but only in a "reasonable" amount. $^{24}$ In a vast number of cases the Internal Revenue Service has successfully challenged the reasonableness of compensation paid by a corporation with the effect that the disallowed portion is treated as a non-deductible dividend. The usual case involves a closely held or family corporation where salaries are arbitrarily scaled to balance out all, or nearly all, of the taxable income of the corporation. In a professional corporation with more than ten shareholders it would seem unlikely that compensation could be fixed by the recipient. Instead, the contribution of effort and experience

22 It is understood that the American Bar Association is currently reviewing the matter. "American Bar Association, Section of Taxation, Report of the Special Committee to Cooperate With ABA Committee on Professional Ethics-Re Association of Attorneys Taxable as Corporations" (July 17, 1961).

23 Int. Rev. Code of 1954, $\$ \$ 1371$ to 1377 , inclusive.

24 Int. Rev. Code of 1954, $\$ 162(a)(1)$. 
to the corporation by the professional employee will control the amount he receives. In effect, if the employee earned or would have earned the income as a partner, it is not logical to say that the amount received as compensation for the same services as a shareholder is unreasonable. Furthermore, a professional corporation is a personal service organization where capital is not an income producing factor. Its shares are all owned by the shareholders rendering services as employees of the corporation, and it is from these services that the corporation derives its income. Investment, with the anticipation of receiving dividends, is missing. For these reasons a controversy over the reasonableness of salaries seems fairly remote.

If there is a desire to retain earnings in the corporation to accumulate capital at a lower tax rate than that of the shareholders, additional corporate income taxes must be considered. The requirements of the personal holding company tax are quite detailed but if other tests are met, ownership of $25 \%$ or more of the stock of a professional corporation by one individual may cause its imposition. ${ }^{25}$ This possibility only arises when there is no election under Subchapter $S$ and the corporation has taxable income. If the accumulation does not exceed $\$ 100,000$, the accumulated earnings tax need not be considered. Beyond that amount, the accumulation must be justified as within the reasonable needs of the business. ${ }^{26}$

As could be expected of novel legislation, some of the provisions of the act may require further clarification. For example, does the legislature have the power to prescribe the forms of association permissible in the practice of law? The Supreme Court of Ohio has stated that the power to regulate, control, and define the practice of law reposes in the judicial branch of the government. ${ }^{27}$ The status of accountants and professional engineers is also unclear. The act amended Section 4715.18 of the Revised Code which formerly prohibited the practice of dentistry under the name of any company, association or corporation. As amended, that section now excepts dental practice in the name of a professional corporation. Somewhat similar prohibitions are contained in Ohio Revised Code, sections 4701.14, relating to accountants, and section 4733.16 , relating to engineers but these sections were not amended by the new act.

It is fairly clear that the language of Revised Code, section 1785.01 (B) limits the purpose of a professional corporation to the practice of one professional service. For example, a professional

25 Int. Rev. Code of 1954, $\S 543$ (a) (5).

26 Int. Rev. Code of 1954, § 535(c).

27 Judd v. City Trust and Savings Bank, 133 Ohio St. 81, 12 N.E.2d 288 (1937). 
corporation may not render both medical and dental services. Section 1785.03 of the bill as originally introduced was as follows:

A professional association may be organized only for the purpose of rendering one specific kind of professional service and shall not engage in any business other than rendering the professional service for which it was organized. However, it may invest its funds in real estate, mortgages, stocks, bonds, or any other type of investment and may own real or personal property necessary or appropriate for rendering its professional service.

This section, deleted from the act, would have apparently limited the powers of a professional corporation to professional service, investments of any type, and ownership of real or personal property necessary or appropriate for rendering its professional service. As the act stands now, a professional corporation has the various powers to carry out its purpose contained in Section 1701.13(F) of the Revised Code, including the power to: "Do all things permitted by law and exercise all authority within the purposes stated in its articles or incidental thereto," as well as power to make investments described in division (G) of the same section, irrespective of purpose. Thus, although the professional corporation may not render two professional services, it appears to have been given some latitude in matters "incidental" to its sole purpose. The question of what is "incidental" to a professional service might cause some differences of opinion. For example, a medical corporation can probably own a building to house its offices, but may it operate a drug store?

Ohio Revised Code section 1785.02, stating that an individual or a group of individuals may organize and become a shareholder, or shareholders, of a professional corporation, makes it clear that the sole practitioner may incorporate himself. There is apparently no requirement that the officers and directors of the professional corporation be shareholders or licensed members of a profession. Thus, for example, the act would permit a large incorporated medical clinic to employ lay business management.

Although the shareholders of a professional corporation must all be licensed to practice in Ohio, it can render its professional services in another state, ${ }^{28}$ provided of course, the other state will permit it. The law of "doing business" will probably have to be re-examined with a view toward this new type of business organization.

The Ohio act places no limitation on the name of the professional corporation. The acts in other states contain language similar to the following:

28 Ohio Rev. Code, § 1701.13(4). 
The corporate name of a professional association shall contain the last names of one or more of the shareholders, or the last names of one or more of the shareholders followed by the word "Chartered," or the last names of one or more of the shareholders followed by the words "Professional Association," or the abbreviation "Prof. Ass'n."

The above was section 1785.10 of the Ohio bill as originally introduced. Apart from ethical considerations, such names as "Ace Personal Injury Service, Inc.," "Painless Extractions, Inc." and "Head to Toe Medical Corporation," would nevertheless be permissible under the act.

As mentioned above the act states that it does not modify any law applicable to the relationship between the person furnishing professional service and the person receiving it. This, for example, would preserve the law of privileged communications. While specifically not modifying the liability arising out of such professional service, the incorporation of a professional partnership does appear to remove the former partner's liability for claims against the partnership arising from conduct other than his own. Regarding the person's own liability as an employee of the corporation, it should be noted that primary liability would be imposed under existing concepts. Query whether if both are sued, the plaintiff must still elect to proceed against one.

The professional corporation cannot have a subsidiary for the practice of a branch of the profession for which it was organized because of the requirement that the shares of a professional corporation be owned only by licensed individuals. However, it is possible for professional corporations to have non-professional subsidiaries if the purpose of the subsidiary may be considered incidental to that of the parent. $^{29}$ For example, a medical corporation could probably incorporate its medical office building. Some other questions regarding stock would include the method of cancelling shares and the status of the stock of a deceased shareholder. These and other considerations point up the fact that an underlying shareholders' agreement is as necessary to a professional corporation as its articles of incorporation.

While one professional corporation may not acquire the stock of another, there is no prohibition against their merger or consolidation. This opens up some rather exotic possibilities where the merged corporation has experienced net operating losses available as carry-overs to the surviving corporation. ${ }^{30}$

The foregoing are some of the obvious implications of various provisions of the act. It is hoped that the purpose of the legislation will be uppermost in the minds of the courts who construe it. If an

29 Ohio Rev. Code, \& 1701.13(3).

30 Int. Rev. Code of 1954, $\S \S 172,381,382$. 
equal tax position is to be attained by professionals through incorporation, the standards of conduct and ethics must be preserved, but so must a workable corporate entity.

At this time the best indications are that the professional corporation will serve its purpose, either directly as an employer, or indirectly as an influence on Congress to equalize the status of the selfemployed professional. The Commissioner of Internal Revenue has been ominously quiet as state after state has circumvented his regulations. At the time of this writing it is informally understood that there could be a challenge to the substance of the characteristics of professional corporations, especially those corporations with one shareholder. Be that as it may, it would appear that the struggle is nearing an end and the relief sought is close at hand. 